\title{
Attitudes and attitude change of students towards the relationship between theory and practice
}

Fischer, Thomas ${ }^{\mathrm{a}}$; Bach, Andreas ${ }^{\mathrm{b}}$ and Rheinländer, Kathrin ${ }^{\mathrm{c}}$

${ }^{a}$ Department of School Education, Europa-Universität Flensburg, Germany, ${ }^{\mathrm{b}}$ School of Education, University of Salzburg, Austria, ${ }^{\mathrm{c}}$ Centre of Academic Further Education, Europa-Universität Flensburg, Germany.

\begin{abstract}
The present study examines the attitudes towards the relationship between theory and practice of students in the context of teaching-oriented Master's programs. The data are based on the project "intensity and stability of jobrelated attitudes in teacher training" (ISabEL), which was conducted at the University of Flensburg. The study analyses the change of student's attitudes towards the relationship of theory and practice during a practical semester. The attitudes were measured using a self-developed scale, which was developed on the basis of a qualitative reconstruction of Thon (2014). The results reveal that the contradiction between theory and practice tends to increase after the practical semester.
\end{abstract}

Keywords: higher education; teacher education; theory practice relationship, attitudes. 


\section{Introduction}

Throughout the past decade, the nexus between theory and practice has gained increasing attention in higher education policy. One of the main driving factors for this recently renewed interest in the relationship between theory and practice has been initiated by the Bologna reform process and the formulated key goal of upgrading the employability of the graduates. Mainly the need to prepare students for the swiftly changing requirements of the global labour market in a knowledge-based society has demanded a shift to more practice orientation (Scott, 2003). Lately, the university-based teacher education in Germany has changed tremendously by the introduction of the so-called practical semester ("Praxissemester") in almost every state (Bosse, 2012). Even if internships are exceedingly appreciated by teacher students (Makrinus, 2013) and although it is argued that bridging the gap between theory and practice needs to expose students with real classroom experiences (Zeichner, 2010), Arnold et al. (2014) have recently asserted a lack of empirical evidence about learning and professional devolvement of students in these new forms of field experiences in teacher education. Particularly in Germany empirically studies on the question of the unintended effects of field experiences that would help to "overcome the naive notion that internships have (quasi-)unlimited benefits" (Arnold et al. 2014, p. 17) are currently sparse. Furthermore, general attitudes of teacher students and especially changes in such attitudes based on practical experiences are still a desideratum, because studies have often examined domain-specific attitudes, especially on mathematics (overview at Fives \& Gill, 2015; Reusser \& Pauli, 2014).

\section{Objectives and research questions}

Against this background, the present study aims to examine new insights into the changes of attitudes of teacher students towards the relationship between theory and practice based on their practical experiences during the practical semester. Therefore, we can formulate the following research questions:

(1) What attitudes towards the relationship between theory and practice have teacher students, and how do they change during a practical semester?

(2) Does the practical semester bridge the gap between theory and practice? 


\section{Theoretical Framework}

In research on teacher education, attitudes or beliefs have long been considered to be an important part of teacher competence (Baumert \& Kunter, 2006). There are different definitions of attitudes as well as synonymous terms such as beliefs, ideas, subjective theories or value systems (see the overview in Calderhead, 1996; Pajares, 1992; Reusser \& Pauli, 2014). Often the aspect of evaluation regarding an object is emphasized as an important defining characteristic. In a widely-used definition, Eagly and Chaiken (1993) define an attitude as "a psychological tendency that is expressed by evaluating a particular entity with some degree of favor or disfavor" (p. 1). Because attitudes are regarded as value judgments, they may differ in terms of their valence and intensity. The strength of an attitude plays a decisive role in the variability of attitudes. Strong attitudes apply as being more stable and more resistant concerning changes over time. Moreover, it is likely that they regulate information processing and behavior.

\section{Methods}

This study is part of the longitudinal research project "Intensity and stability of job-related attitudes" (ISabEL), which is being carried out at the University of Flensburg since 2014. The project aims at measuring the change of job-related attitudes of teacher students in the context of academic and practical phases. It takes individual and institutional characteristics into account. The scale of the present sub-study is based on a qualitative study of Thon (2014) who has reconstructed three dimensions of the relationship between theory and practice of teacher students in a Bachelor's programme (1. practice orientation as a condition of comprehension, 2. application of theory to practice and 3. independence between theory and practice). The items were formulated in the sense of an attitude as an evaluative judgment. The survey covered a four-stage response format (Likert scale) with respect to the consent to the statements $(1=$ "not true" to $4=$ "exactly true"). The dimensionality of the scale was tested in a preliminary study. The scale was part of a prepost study within a 10-week internship (practical semester). Thereby the three-factor structure of the scale was tested again, using confirmatory factor analysis. The analysis was conducted with the program M-Plus. In accordance with the recommendations of various researchers, the present study used several fit indices to evaluate the adequacy of the specified model. In addition to the $\chi 2$-test, the fit indices CFI, RMSEA and SRMR are reported. The model evaluation was based on the recommendations of Schermelleh-Engel et al. (2003). The analysis of mean differences of attitudes toward the complexity of teaching was carried out using a t-test for dependent samples. 


\section{Data sources}

The sample of the present analysis included the cohort of Master's students in the practical semester. This is implemented at the University of Flensburg for 10 weeks in the third semester of the Master's degree programs, for teaching both at primary schools and at comprehensive schools (lower secondary level). The first data collection took place in October 2014. Altogether $78.62 \%$ or 239 of the 304 student teachers participated in the questionnaire survey, carried out during an introductory session on the practical semester. At this time $47.7 \%$ of the teacher students were registered for the Master of Education program for primary school and $52.3 \%$ for the Master of Education program for comprehensive school. A total of $78.6 \%$ of the teacher students were female. During the second data collection in February 2015233 teacher students (76.64\%) were surveyed again. The survey was executed in an obligatory course of the practical semester.

\section{Results}

Table 1 shows the sub-dimensions of the scale "attitudes towards the relationship between theory and practice" with an item example for each dimension and the internal consistency for pre- and post-surveys. The Cronbach Alphas are between .67 and .87 and can be assessed as being acceptable to good. The specified measurement model for the scale has an acceptable model fit $\left(\chi^{2}=60.71[\mathrm{df}=41], \mathrm{p}=.02 ; \mathrm{CFI}=.97 ; \mathrm{RMSEA}=.05 ; \mathrm{SRMR}=\right.$ .05 ) (see Figure 1). Almost all indicators load high on the three distinguished latent factors $(\lambda=.44$ to $\lambda=.84)$. All indicators contribute significantly to the explained variance.

Table 2 presents the means and standard deviations of the pre-post survey and the results of T-test for dependent samples. For the first measurement point, the findings show average differences between the dimensions of attitudes toward the relationship between theory and practice. The highest agreement shows up for the dimension "practice orientation as a condition of comprehension", followed by the dimensions "application of theory to practice". The lowest mean value appears for the dimension "independence between theory and practice".

The results also reveal that two of three dimensions of the sub-dimensions significantly change within the practical semester in the direction of less approval for the dimension "practice orientation as a condition of comprehension" and for more approval for the dimension "independence between theory and practice" The effect size of the mean differences can be regarded as small effects (see Cohen, 1988). The effect is for the dimension "practice orientation as a condition of comprehension" is $\mathrm{d}=.20$ and for the dimension "independence between theory and practice" $\mathrm{d}=.10$. 
Table 1. Sub dimensions of the scale "attitudes towards the relationship between theory and practice" and statistical values.

\begin{tabular}{|c|c|c|c|}
\hline Subscale & Item example & $\begin{array}{c}\alpha \\
\text { pre }\end{array}$ & $\begin{array}{c}\alpha \\
\text { post }\end{array}$ \\
\hline $\begin{array}{l}\text { practice orientation as } \\
\text { a condition of } \\
\text { comprehension (POC) } \\
\text { (4 items) }\end{array}$ & $\begin{array}{l}\text { Practice orientation makes the theory } \\
\text { clear. }\end{array}$ & .84 & .86 \\
\hline $\begin{array}{l}\text { application of theory to } \\
\text { practice (APL) } \\
\text { (4 items) }\end{array}$ & Theories have to be applicable. & .67 & .70 \\
\hline $\begin{array}{l}\text { independence between } \\
\text { theory and practice } \\
\text { (IND) } \\
\text { (3 items) }\end{array}$ & Theory and practice are not the same. & .68 & .70 \\
\hline
\end{tabular}

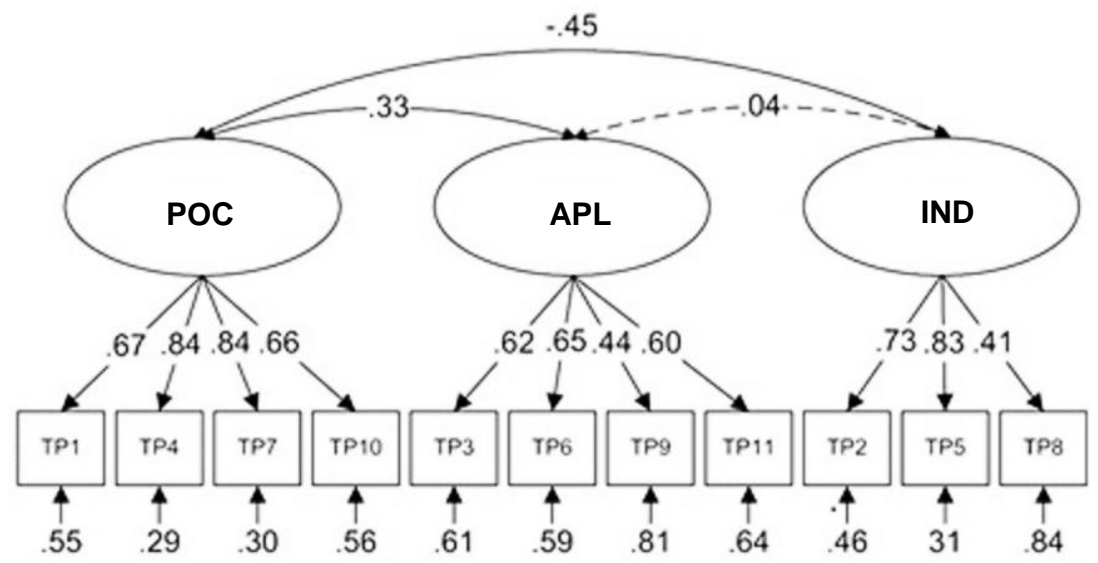

Figure 1.Three-factor-model of the scale "attitudes towards the relationship between theory and practice". 
Table 2. Mean differences in the attitudes toward the relationship between theory and practice

\begin{tabular}{lcccc} 
& $\begin{array}{c}\text { M (SD) } \\
\text { pre }\end{array}$ & $\begin{array}{c}\text { M (SD) } \\
\text { post }\end{array}$ & t (df) & Cohen's d \\
& & $3.38(.63)$ & $-2.72(223)^{*}$ & .21 \\
\hline $\begin{array}{l}\text { practice orientation as } \\
\text { a condition of } \\
\text { comprehension (POC) }\end{array}$ & $3.50(.54)$ & & & \\
\hline
\end{tabular}

\begin{tabular}{lllll}
\hline $\begin{array}{l}\text { application of theory to } \\
\text { practice }(A P L)\end{array}$ & $3.15(.56)$ & $3.20(.57)$ & $1.15(176)$ & 0.04 \\
& & & & \\
\hline $\begin{array}{l}\text { independence between } \\
\text { theory and practice } \\
(I N D)\end{array}$ & $2.19(.67)$ & $2.32(.66)$ & $2,46(214)^{*}$ & .10 \\
\hline
\end{tabular}

\section{Discussion}

The present sub-study aimed to develop an instrument that can measure the attitudes towards the relationship between theory and practice, based on a reconstruction by Thon (2014). The postulated three-factorial structure of the construct is empirically detectable. For the specified model, acceptable model fit values could be determined. The analysis of the reliability showed adequate internal consistency for the three sub-scales. In the longitudinally pre-post study could be shown, that the attitudes of teacher students differ in a statistically significant manner between the measurement periods for two dimensions. The dimension "practice orientation as a condition of comprehension" significantly decreased while the dimension "independence between theory and practice" significantly increased in the post study. The empirical findings suggest that the contradiction between theory and practice tends to increase after the practical semester. Thus, we can conclude that the practical semester does not bridge the gap between theory and practice. Following the present findings, the changes in attitudes in the practical semester should be compared with different phases of the teacher education program. It should be proved, on which certain conditions these changes are dependent, or in what interaction they stand with selected individual characteristics of the student teacher. 


\section{References}

Arnold, K.-H., Gröschner, A., \& Hascher, T. (2014). Pedagogical field experiences in teacher education: Introduction to the research area. In K.-H. Arnold, A. Gröschner, \& T. Hascher (Eds.), Schulpraktika in der Lehrerbildung. Theoretische Grundlagen, Konzeptionen, Prozesse und Effekte (pp. 11-28). Münster: Waxmann.

Baumert, J., \& Kunter, M. (2006). Stichwort: Professionelle Kompetenz von Lehrkräften. Zeitschrift für Erziehungswissenschaft, 9(4), 469-520.

Bosse, D. (2012). Zur Situation der Lehrerbildung in Deutschland. In L. Criblez, D. Bosse, \& T. Hascher (Eds.), Reform der Lehrerbildung in Deutschland, Österreich und der Schweiz (Vol. 4, pp. 11-28). Immenhausen: Prolog-Verl.

Calderhead, J. (1996). Teachers: Beliefs and knowledge. In D. C. Berliner \& R. C. Calfee (Eds.), Handbook of educational psychology (pp. 709-725). New York, London: Macmillan Library Reference USA, Simon \& Schuster Macmillan; Prentice Hall International.

Cohen, J. (1988). Statistical power analysis for the behavioral sciences. Hillsdale: Erlbaum.

Eagly, A. H., \& Chaiken, S. (1993). The psychology of attitudes. Belmont, Calif: Wadsworth Thompson.

Fives, H., \& Gill, M. G. (Eds.). (2015). Educational psychology handbook. International handbook of research on teachers' beliefs. New York: Routledge.

Makrinus, L. (2013). Der Wunsch nach mehr Praxis: Zur Bedeutung von Praxisphasen im Lehramtsstudium. Wiesbaden: Springer VS.

Pajares, F. M. (1992). Teachers' Beliefs and Educational Research: Cleaning up a Messy Construct, 62(3), 307-332.

Reusser, K., \& Pauli, C. (2014). Berufsbezogene Überzeugungen von Lehrinnen und Lehrern. In E. Terhart, H. Bennewitz, \& M. Rothland (Eds.), Handbuch der Forschung zum Lehrerberuf (pp. 642-661). Münster, Westf: Waxmann.

Schermelleh-Engel, K., Moosbrugger, H., \& Müller, H. (2003). Evaluating the fit of structural equation models: Tests of significance and descriptive goodness-of-fit measures, 8(2), 23-74.

Scott, P. (2003). Challenges to Academic Values and the Organization of Academic Work in a Time of Globalization. Higher Education in Europe, 28(3), 295-306.

Thon, C. (2014). Theorie und Praxis in der universitären Lehre: Empirische Rekonstruktionen studentischer Verhältnisbestimmungen. In U. Unterkofler \& E. Oestreicher (Eds.), Wissensentwicklung in Professionen. Herausforderungen für Wissenschaft und Praxis (pp. 219-237). Leverkusen: Budrich.

Zeichner, K. (2010). Rethinking the Connections Between Campus Courses and Field Experiences in College- and University-Based Teacher Education. Journal of Teacher Education, 61(1-2), 89-99. 